\title{
EFEKTIVITAS PENGAWASAN KANTOR IMIGRASI KELAS I TANGERANG TERHADAP PENYALAHGUNAAN IZIN TINGGAL KUNJUNGAN WARGA NEGARA ASING UNTUK BEKERJA BERDASARKAN UNDANG-UNDANG NO 6 TAHUN 2011 TENTANG KEIMIGRASIAN
}

\author{
Rizqy Claudya Novella \\ Abdul Kadir \\ Rizqyclaudya@gmail.com \\ abdulkadir.usman87@yahoo.com
}

\section{Fakultas Hukum Universitas Muhammadiyah Tangerang}

\begin{abstract}
ABSTRAK
Judul penelitian ini adalah "Efektivitas Pengawasan Kantor Imigrasi Kelas 1 Tangerang Terhadap Penyalahgunaan Izin Tinggal Kunjungan Warga Negara Asing untuk Bekerja Berdasarkan Undang-undang No 6 Tahun 2011 Tentang Keimigrasian". Rumusan masalah penelitian ini yaitu Bagaimana efektivitas pengawasan yang dilakukan oleh kantor imigrasi kelas 1 Tangerang bagi warga negara asing yang menyalahi izin tinggal kunjungan menurut Undang-undang No 6 Tahun 2011 tentang keimigrasian dan Bagaimana penyelesaian hukum bagi warga negara asing yang menyalahgunakan izin tinggal kunjungan untuk bekerja di kantor imigrasi kelas 1 tangerang. Metode penelitian ini ada normatif empiris. Sumber data primernya yang digunakan adalah dengan wawancara, studi pustaka, dokumentasi, dan observasi. Kemudian data yang dikumpulkan secara kualitatif. Hasil penelitian penelitian ini adalah warga negara asing bisa dipertanggungjawabkan pidana atau tindakan administratif keimigrasian apabila terbukti menyalahgunakan izin yang telah diberikan dikenakan pasal 122 dan pasal 75 Undang-undang No 6 Tahun 2011 tentang keimigrasian. Untuk menerapkan sanksi pidana dan tindakan administratif pada kasus penyalahgunaan izin tinggal kunjungan bagi warga negara asing maka harus dilakukan penyelidikan dan penyidikan terlebih dahulu oleh tim pengawasan dan penyidikan kantor imigrasi kelas 1 tangerang terhadap warga negara asing yang menyalahgunakan izin tinggal kunjungan.
\end{abstract}

Kata Kunci: Imigrasi, Izin Tinggal Kunjungan, Warga Negara Asing

\section{ABSTRACT}

The title of this thesis is "The Effectiveness of Tangerang Class 1 Immigration Office Supervision Against Abuse of Foreign Residents Visit Permits to Work Under Law No. 6 of 2011 Regarding Immigration". The formulation of this thesis is how the effectiveness of supervision conducted by the Tangerang 1 class immigration office for foreign nationals who violate the residence permit according to Law No. 6 of 2011 concerning immigration and how the legal settlement for foreign citizens who abuse the residence permit for visiting work at the immigration office in class 1, tangerang. This research method is empirical normative. The primary data sources used are interviews, literature study, documentation, and observation. Then the data collected qualitatively. The results of this thesis research are that foreign citizens can be held liable for criminal or administrative immigration actions if they are proven to misuse the licenses that have been given subject to article 122 and article 75 of Law No. 6 of 2011 concerning immigration. To apply criminal sanctions and administrative actions in cases of abuse of residence permit for foreign citizens, an investigation and investigation must be carried out first by the surveillance and investigation team of the tangerang class 1 immigration office against foreign nationals who abuse the residence permit. 


\section{Pendahuluan}

Faktor ekonomi merupakan faktor terbesar yang menjadi dasar seseorang melakukan Migrasi. Para imigran lebih memilih untuk mendatangkan negara berkembang. Sebab negara berkembang membutuhkan tenaga ahli yang berpengalaman untuk membantu meningkatkan kesejahteraan negara tujuan. keadaan ekonomi yang beragam dari negara yang berbeda menjadi alasan kuat yang sangat berpengaruh bagi orang-orang yang ingin mendapatkan kehidupan yang lebih stabil. Para warga negara asing atau imigran memiliki prinsip untuk meningkatkan kualitas hidupnya di negara tujuan, umumnya mereka akan mencari negara yang sedang berkembang dimana terdapat banyak kesempatan untuk bergabung menjadi tenaga kerja. ${ }^{1}$

Beberapa negara berkembang khususnya di Indonesia, kehadiran Warga Negara Asing di percaya memberikan banyak keuntungan dari segi kehidupan ekonomi. Hal ini dibuktikan dengan adanya dukungan dari pemerintah yang membuka bebas investasi dan spesifikasi jabatan yang dibutuhkan kepada Warga Negara Asing untuk bergabung untuk membantu meningkatkan kesejahteraan negara tujuan.

Dari sisi positif Tenaga Kerja Asing memberikan dukungan terhadap perkembangan suatu negara, sebab pengalaman dan ide kreatif yang mereka sumbangkan sangat di butuhkan di samping itu kehadiran Tenaga Kerja Asing juga menimbulkan dampak negatif terhadap keamanan suatu negara seperti menurunnya kualitas sumber daya manusia, pembatasan lowongan pekerjaan tertentu dan menjadi ancaman bagi pekerja lokal yang tidak memiliki keterampilan lebih. ${ }^{2}$

Tujuan penggunaan Tenaga Kerja Asing di Indonesia adalah untuk memenuhi keterampilan dan daya profesional di bidang tertentu yang belum dapat di isi oleh Tenaga Kerja Indonesia (TKI). Keberadaan Tenaga Kerja Asing di Indonesia dapat membimbing Tenaga Kerja Indonesia dalam bidang keahlian di suatu perusahaan serta mempercepat proses pembangunan Nasional dan meningkatkan investasi asing sebagai penunjang pembangunan di Indonesia. ${ }^{3}$

Kehadiran para pekerja asing adalah suatu kebutuhan karena Indonesia masih membutuhkan tenaga-tenaga ahli asing dalam pengembangan Sumber Daya Manusia di berbagai sektor ekonomi di Indonesia. Sementara itu kehadiran Tenaga Kerja Asing juga dapat menjadi sebuah tantangan bagi masyarakat Indonesia karena Tenaga Kerja Asing meminimalisir kesempatan Tenaga Kerja Indonesia dalam mendapat sebuah pekerjaan di perusahaan. Masalah ketenagakerjaan di masa datang akan terus berkembang semakin kompleks sehingga memerlukan penanganan yang lebih serius dan dipandang sangat penting bagi pihak keimigrasian. Pada masa perkembangan tersebut pergeseran nilai dan

${ }^{1}$ H.Ayu, Penegakan Hukum Keimigrasian Terhadap Penyalahgunaan Visa, http://eprints.ums.ac.id, hlm 2, dikunjungi pada tanggal 28 April 2019 pukul 23.00.

${ }^{2}$ Desy Fatma, 8 Dampak Tenaga Kerja Asing di Indonesia, https://ilmugeografi.com, 8 Juni 2018, hlm.2, dikunjungi pada tanggal 05 Mei 2019 pukul 23.15

${ }^{3}$ Budiono, Abdul Rachmat, Hukum Perburuhan di Indonesia, (Jakarta: PT.Rajagrafindo Persada), 1995, hlm 115. 
tata kehidupan akan banyak terjadi. Pergeseran yang dimaksud tidak jarang melanggar peraturan perundang-undangan yang berlaku. ${ }^{4}$

Menghadapi pergeseran nilai dan tata kehidupan para pelaku industri dan perdagangan, pengawasan ketenagakerjaan dituntut untuk mampu mengambil langkahlangkah antisipatif serta mampu menampung segala perkembangan yang terjadi. Oleh karena itu penyempurnaan terhadap sistem pengawasan ketenagakerjaan harus di laksanakan agar peraturan Perundang - undangan dapat dilakukan secara efektif oleh para pelaku industri dan perdagangan. Dengan demikian pengawasan ketenagakerjaan sebagai suatu sistem mengemban misi dan fungsi agar peraturan perundang-undangan di bidang ketenagakerjaan dapat ditegakan. Penerapan peraturan perundang-undangan ketenagakerjaan juga dimaksudkan untuk menjaga keseimbangan antara hak dan kewajiban bagi pengusaha atau pekerja atau buruh sehingga kelangsungan usaha serta ketenagakerjaan dalam rangka meningkatkan produktivitas kerja dan kesejahteraan tenaga kerja dapat terjamin (Penjelasan atas UU No 21 Thn 2003 tentang pengesahan konvensi ILO No 81 tentang Pengawasan Ketenagakerjaan dalam indstri dan perdagangan.

Peraturan Perundang-undangan Indonesia, sebagaimana disebutkan pada pasal 1 ayat 13 Undang-undang Nomor 13 Tahun 2003 Tentang Ketenagakerjaan yang menyebutkan bahwa Tenaga Kerja Asing adalah warga negara asing pemegang visa dengan maksud untuk bekerja di wilayah Indonesia. Tentunya memiliki persyaratan dan ketentuan yang harus dipenuhi oleh warga negara asing, yaitu :

1. Permohonan RPTKA (Rencana Penggunaan Tenaga Kerja Asing);

2. Permohonan Notifikasi ;

3. Permohonan Visa (VITAS/Visa Tinggal Terbatas) pada perwakilan Republik Indonesia di luar negeri;

4. Diberikan VITAS untuk masuk ke wilayah Indonesia;

5. Pemerikasaan warga negara asing di Tempat Pemeriksaan Imigrasi (TPI) di pelabuhan udara/laut/darat;

6. Pemberian Izin Keimigrasian dan melaporkan kepada Imigrasi setempat

Meningkatnya Tenaga Kerja Asing di Indonesia menurut data Ditjen Imigrasi Kementerian Hukum dan HAM per 18 Desember 2016 jumlah rata - rata Tenaga Kerja Asing di Indonesia periode 2011-2016 mencapai 71.776 TKA ,dan jumlah Tenaga Kerja Asing hingga akhir 2018 mencapai 95.335 TKA, angka ini meningkat 10,88\% dibandingkan dengan 2017 yang mencapai 85.974 TKA. ${ }^{5}$ Kementerian ketenagakerjaan mencatat jumlah Tenaga Kerja Asing asal China sebagai negara paling banyak mengirimkan tenaga kerjanya di Indonesia.

Saat ini jumlah orang asing yang melakukan perjalanan ke Indonesia terus bertambah di mana hal ini bisa menimbulkan kemungkinan terancamnya keamanan negara yang ditandai dengan meningkatnya potensi penyalahgunaan izin masuk,

\footnotetext{
${ }^{4}$ Agusmidah, Dilematika Hukum Ketenagakerjaan Tinjauan Politik Hukum, (Medan: PT.Sofmedia), 2011,hlm.50.

${ }^{5}$ Anonim,Tenaga Kerja Asing di Indonesia Meningkat $11 \%$ pada 2018, www.databoks.katadata.co.id, 23 Maret 2019, hlm.1, dikunjungi pada tanggal 11 april 2019 pada pukul 13.00.
} 
khususnya bagi orang asing yang ingin bekerja di Indonesia. Hal ini sering terjadi di karenakan ketatnya peraturan perolehan izin kerja bagi orang asing yang ingin bekerja di Indonesia, yang tentunya mempengaruhi proses untuk mendapatkan Visa kerja. Sebab, tanpa Visa kerja orang asing tidak bisa masuk dan bekerja di Indonesia sesuai dengan yang diharapkan sehingga perolehan Visa menjadi faktor penghambat utama dikalangan Warga Negara Asing bahkan pengguna Tenaga Kerja Asing.

Penyalahgunaan visa karena prosedur untuk mendapatkan visa terutama visa untuk bekerja yang memerlukan banyak waktu, sehingga warga negara asing lebih banyak memilih menggunakan visa sementara atau visa kunjungan. Visa sementara atau visa kunjungan adalah salah satu alternatif yang lebih cepat untuk bisa datang ke Indonesia, beberapa warga negara asing bahkan ada yang menggunakan visa kunjungan untuk bekerja secara diam - diam. Dari segi ekonomi warga negara asing yang menggunakan visa kunjungan di anggap sebagai turis. Mereka yang menggunakan visa kunjungan bisa mengurangi budget financial karena mereka tidak perlu membayar pajak sebagai Tenaga Kerja Asing sesuai dengan yang dibebankan oleh pemerintah dalam permenakertrans no 16 tahun $2015 .^{6}$

Penyalahgunaan Izin Tinggal oleh Warga Negara Asing dengan menggunakan Visa Kunjungan Wisata kerap kali terjadi, umumnya digunakan dalam rangka bekerja sebagai Tenaga Kerja Asing (TKA) pada Perusahaan Penanaman Modal Asing (PMA) di Indonesia. Hal ini menyebabkan menjadi berkurangnya kesempatan kerja bagi Tenaga Kerja Indonesia di dalam negeri dan berkurangnya pendapatan Negara dari sisi pengunaan Tenaga Kerja Asing. Berdasarkan fakta di lapangan, masalah penyalahgunaan Izin Tinggal Kunjungan Wisata umumnya berasal dari Pemberian Visa On Arrival (VOA) dan Bebas Visa Kunjungan Wisata. ${ }^{7}$

Terkait pelanggaran yang dilakukan oleh Warga Negara Asing, mereka diduga melanggar Undang-Undang Nomor 6 Tahun 2011 Tentang Keimigrasian, Pasal yang dilanggar bervariasi mulai dari overstay, tidak dapat menunjukkan paspor ketika diminta petugas sebagaimana di atur di Pasal 116, hingga penyalahgunaan Izin Tinggal Keimigrasian sebagaimana di atur di Pasal 122, mereka dapat dikenakan Tindakan Administratif Keimigrasian berupa membayar biaya beban/denda, Deportasi dan penangkalan maupun sanksi pidana dengan ancaman pidana penjara Maksimal 5 (lima) tahun sebagaimana diatur dalam Undang-Undang Nomor 6 Tahun 2011 Tentang Keimigrasian.

Dengan adanya hal tersebut khususnya masalah penggunaan Tenaga Kerja Asing di Indonesia perlu mendapat perhatian serius dari pemerintah khususnya dalam pengawasan kegiatan Tenaga Kerja Asing selama berada di Indonesia, agar penggunaan Tenaga Kerja Asing dapat bermanfaat bagi Indonesia dalam mengelola kekayaan alamnya dan mempercepat pembangunan. Pemberian kemudahan Visa dalam rangka meningkatkan devisa negara di bidang pariwisata terhadap Warga Negara Asing yang

\footnotetext{
${ }^{6}$ H.Ayu, Op.Cit. hlm. 7.

${ }^{7}$ Abharina Atikah Sari, Pengawasan Tenaga Kerja Asing di Kota Cilegon, Skripsi, Fakultas Hukum Universitas Sultan Ageng Tirtayasa, Serang, hlm. 50.
} 
akan memasuki Indonesia, tentunya harus dibarengi dengan pengawasan terhadap Izin Tinggalnya di Indonesia. ${ }^{8}$

Maka kegiatan pengawasan sangat di perlukan terutama untuk mengamati, mencegah, dan menindak apabila warga negara asing tersebut melakukan pelanggaran izin tinggal atau melakukan kegiatan yang tidak sesuai dengan izin tinggal yang diberikan kepada Warga Negara Asing tersebut selama berada di wilayah Indonesia. Sebagaimana di atur dalam undang-undang Nomor 6 tahun 2011 Tentang Keimigrasian, dalam Bab VI pasal 66-73 yang mengatur Tentang Pengawasan Keimigrasian.

Dalam Pengawasan yang dilakukan oleh Tim Direktorat Jenderal Imigrasi Kota Tangerang di area Kota Tangerang, pengawasan yang dipimpin langsung oleh Kepala Kantor Imigrasi Tangerang, Herman Lukman . Dalam pengawasan tersebut tim mengamankan 7 Tenaga Kerja Asing asal Tiongkok yang melakukan Penyalahgunaan Izin Tinggal, terhadap 7 Tenaga Kerja Asing tersebut akan dilakukan pemeriksaan secara intensif di Kantor Imigrasi Kelas 1 Tangerang. ${ }^{9}$

Tentu melihat data diatas dan realitas mengenai adanya penyalahgunaan izin tinggal, maka penulis tertarik untuk meneliti dan mengkaji dengan judul Efektivitas

Pengawasan Kantor Imigrasi Kelas 1 Tangerang Terhadap Penyalahgunaan Izin Tinggal Kunjungan Warga Negara Asing Untuk Bekerja Berdasarkan Undang-Undang Nomor 6 Tahun 2011 Tentang Keimigrasian.

Berdasarkan identifikasi masalah di atas, maka rumusan masalah yang di bahas dalam penelitian ini adalah Bagaimana Efektivitas Pengawasan yang dilakukan oleh Kantor Imigrasi Kelas 1 Tangerang bagi Warga Negara Asing yang menyalahi Izin Tinggal Kunjungan Menurut UU No 6 Tahun 2011 Tentang Keimigrasian, Bagaimana Penyelesaian Hukum bagi Warga Negara Asing yang Menyalahgunakan Izin Tinggal Kunjungan untuk bekerja di Kantor Imigrasi Kelas 1 Tangerang.

Dari perumusan masalah yang diambil, maka tujuan penelitian ini Untuk Mengetahui Efektivitas Pengawasan yang dilakukan oleh Kantor Imigrasi Kelas 1 Tangerang bagi Warga Negara Asing yang Menyalahi Izin Tinggal Kunjungan Menurut UU No 6 tahun 2011 Tentang Keimigrasian dan Untuk Mengetahui Penyelesaian Hukum bagi Warga Negara Asing yang Menyalahgunakan Izin Tinggal Kunjungan untuk bekerja oleh Kantor Imigrasi Kelas 1 Tangerang.

\section{Metode Penelitian}

Merupakan seluruh rangkaian kegiatan yang akan dilakukan dalam rangka menjawab pokok permasalahan atau untuk membuktikan pernyataan awal yang

\footnotetext{
${ }^{8}$ Bugie Kurniawan, Analisis Terhadap Pelaksaaan Manajemen Pemberian VOA yang dilaksanakan oleh Direktorat Jenderal Imigrasi dan Tempat Pemeriksaan Imigrasi, http://lib.ui.ac.id, 2008, hlm.1, dikunjungi pada tanggal 16 April 2019 pada pukul 14.00.

${ }_{9}$ https://tangerang-imigrasi.go.id, 09 Mei 2018, dikunjungi pada tanggal 13 April 2019 pada pukul 20.00
} 
dikemukakan dan memperdalam suatu gejala tertentu sehingga menghasilkan suatu rangkaian proses penelitian yang dapat di pertanggung jawabkan berdasarkan suatu parameter kebenaran ilmiah. Adapun metode penelitian yang digunakan oleh penulis dalam penelitian Jenis penelitian yang penulis gunakan adalah jenis penelitian hukum normatif-empiris, Penelitian hukum normatif-empiris adalah penelitian hukum mengenai pemberlakuan ketentuan hukum normatif (undang-undang) secara in action pada setiap peristiwa hukum tertentu yang terjadi dalam masyarakat. Penulis menggunakan penelitian hukum normatif-empiris untuk menjawab rumusan masalah kedua yang mengkaji penyelesaian hukum bagi warga negara asing yang menyalahgunakan izin tinggal, yang penyelesaiannya di masyarakat sudah sesuai atau belum dengan Undang-undang No 6 Tahun 2011 Tentang Keimigrasian. Sedangkan penulis menggunakan penelitian empiris untuk menjawab rumusan masalah pertama yaitu efektivitas pengawasan Kantor Imigrasi Kelas 1 Tangerang terhadap penyalahgunaan izin tinggal, penelitian ini menggunakan pengumpulan data observasi dan wawancara yang dilakukan di Kantor Imigrasi Kelas 1 Tangerang dengan Kepala Kantor Imigrasi Tangerang.

Sumber Data dibagimenjadi dua yaitu Data Primer adalah data yang diperoleh secara langsung dari sumbernya. Dalam hal ini peneliti melakukan observasi, wawancara dan dokumentasi dengan Kepala Kantor Imigrasi Tangerang berkaitan dengan penyalahgunaan izin tinggal warga negara asing di Tangerang.

Sedangkan Data Sekunder adalah data yang di peroleh peneliti dari sumber yang sudah ada. Data sekunder dalam penelitian ini adalah Undang-undang No 6 Tahun 2011 Tentang Keimigrasian serta melalui dokumen-dokumen tidak resmi, buku-buku yang berhubungan dengan objek penelitian, hasil penelitian

\section{Hasil Penelitian Dan Analisis}

\section{Data Warga Negara Asing di Kantor Imigrasi Kelas 1 Tangerang Periode 2016 - Juni 2019}

Di bawah ini merupakan data Warga Negara Asing di Imigrasi kelas I Tangerang periode tahun 2016 sampai Juni 2019 yang terdiri dari 3 wilayah yaitu Kota Tangerang, Kabupaten Tangerang, Kota Tangerang Selatan. Dari data pada tahun 2016 di wilayah Kabupaten Tangerang terdapat Warga Negara Asing yang paling banyak dengan jumlah 3427 orang (2408 laki laki dan 1019 perempuan), dan di wilayah Kota Tangerang Selatan yang paling sedikit adanya Warga Negara Asing dengan jumlah 1226 orang (820 laki laki dan 406 perempuan). Pada Tahun 2017 di wilayah Kabupaten Tangerang yang paling banyak adanya Warga Negara Asing dengan jumlah 4076 (2733 laki-laki dan 1343 perempuan), dan yang paling sedikit adanya Warga Negara Asing ada di wilayah Kota Tangerang Selatan, dengan jumlah 992 orang (675 laki-laki dan 317 perempuan). Pada tahun 2018 yang terdapat banyak Warga Negara Asing di wilayah Kabupaten Tangerang dengan jumlah 4276 orang (2918 laki-laki dan 1358 Perempuan) dan yang paling sedikit di wilayah Kota Tangerang Selatan 
dengan jumlah Warga Negara Asing 1188 orang (802 laki-laki dan 386 perempuan). Pada Tahun 2019 di wilayah Kabupaten Tangerang terdapat yang paling banyak Warga Negara Asing yaitu sejumlah 3172 orang (2232 laki-laki dan 940 perempuan) dan yang paling sedikit di wilayah Kota Tangerang Selatan yaitu 787 orang (544 laki-laki dan 243 perempuan).

\section{Data Warga Negara Asing yang Memiliki ITAP di Kantor Imigrasi Kelas 1 Tangerang Periode 2016 - Juni 2019}

ITAP adalah Izin Tinggal Tetap, diberikan kepada Warga Negara Asing yang telah menetap di wilayah Indonesia secara berturut-turut selama 5 Tahun dan memenuhi persyaratan-persyaratan keimigrasian. Di bawah ini merupakan data Warga Negara Asing yang memiliki ITAP yang terdapat di Kantor Imigrasi Kelas I Tangerang Periode 2016 hingga Juni 2019 yang terdiri dari 3 wilayah yaitu Kota Tangerang, Kabupaten Tangerang, Dari data pada tahun 2016 di wilayah Kabupaten Tangerang terdapat Warga Negara Asing yang mempunyai ITAP paling banyak dengan jumlah 293 orang (210 laki laki dan 83 perempuan), dan di wilayah Kota Tangerang yang paling sedikit adanya Warga Negara Asing yang memiliki ITAP dengan jumlah 89 orang (69 laki laki dan 20 perempuan).

Pada Tahun 2017 di wilayah Kabupaten Tangerang yang paling banyak adanya Warga Negara Asing memiliki ITAP dengan jumlah 401 (282 laki-laki dan 119 perempuan), dan yang paling sedikit adanya Warga Negara Asing yang memiliki ITAP ada di wilayah Kota Tangerang, dengan jumlah 95 orang (69 laki-laki dan 26 perempuan). Pada tahun 2018 yang terdapat banyak Warga Negara Asing yang memiliki ITAP di wilayah Kabupaten Tangerang dengan jumlah 353 orang (248 laki-laki dan 105 Perempuan) dan yang paling sedikit di wilayah Kota Tangerang dengan jumlah Warga Negara Asing memiliki ITAP 102 orang (75 laki-laki dan 27 perempuan). Pada Tahun 2019 di wilayah Kabupaten Tangerang terdapat yang paling banyak Warga Negara Asing yang memiliki ITAP yaitu sejumlah 315 orang (226 laki-laki dan 89 perempuan) dan yang paling sedikit di wilayah Kota Tangerang yaitu 106 orang (80 laki-laki dan 26 perempuan).

\section{Data Warga Negara Asing yang Memiliki ITAS di Kantor Imigrasi Kelas 1 Tangerang Periode 2016 - Juni 2019}

ITAS adalah Izin Tinggal Terbatas, diberikan kepada Warga Negara Asing yang memenuhi persyaratan-persyaratan keimigrasian dan mengajukan permohonan tinggal untuk jangka waktu terbatas di wilayah Indonesia, baik karena pekerjaan atau alasan-alasan lain yang sah tersebut. Di bawah ini merupakan data Warga Negara Asing yang memiliki ITAS yang terdapat di Kantor Imigrasi Kelas I Tangerang Periode 2016 hingga Juni 2019 yang terdiri dari 3 wilayah yaitu Kota Tangerang, Kabupaten Tangerang, Kota Tangerang Selatan, Dari data pada tahun 2016 di wilayah Kabupaten Tangerang terdapat 
Warga Negara Asing yang mempunyai ITAS paling banyak dengan jumlah 3036 orang (2122 laki laki dan 914 perempuan), dan di wilayah Kota Tangerang yang paling sedikit adanya Warga Negara Asing yang memiliki ITAS dengan jumlah 1084 orang (715 laki laki dan 369 perempuan). Pada Tahun 2017 di wilayah Kabupaten Tangerang yang paling banyak adanya Warga Negara Asing memiliki ITAS dengan jumlah 3533 (2346 laki-laki dan 1187 perempuan), dan yang paling sedikit adanya Warga Negara Asing yang memiliki ITAS ada di wilayah Kota Tangerang, dengan jumlah 875 orang (592 laki-laki dan 283 perempuan). Pada tahun 2018 yang terdapat banyak Warga Negara Asing yang memiliki ITAS di wilayah Kabupaten Tangerang dengan jumlah 3625 orang (2425 laki-laki dan 1200 Perempuan) dan yang paling sedikit di wilayah Kota Tangerang dengan jumlah Warga Negara Asing memiliki ITAS 1045 orang (700 laki-laki dan 345 perempuan). Pada Tahun 2019 di wilayah Kabupaten Tangerang terdapat yang paling banyak Warga Negara Asing yang memiliki ITAS yaitu sejumlah 2826 orang (1981 laki-laki dan 845 perempuan) dan yang paling sedikit di wilayah Kota Tangerang yaitu 664 orang (454 laki-laki dan 210 perempuan).

\section{Data Warga Negara Asing yang Memiliki ITK di Kantor Imigrasi Kelas 1 Tangerang Periode 2016 - Juni 2019}

ITK adalah Izin Tinggal Kunjungan, diberikan kepada Warga Negara Asing yang berkunjung ke wilayah Indonesia untuk waktu yang singkat dalam rangka tugas pemerintahan, pariwisata, kegiatan sosial budaya atau usaha. Jangka waktu izin kunjungan disesuaikan dengan keperluan atau jadwal kegiatan tersebut, paling lama 60 hari. Di bawah ini merupakan data Warga Negara Asing yang memiliki ITK yang terdapat di Kantor Imigrasi Kelas I Tangerang Periode 2016 hingga Juni 2019 yang terdiri dari 3 wilayah yaitu Kota Tangerang, Kabupaten Tangerang, Kota Tangerang Selatan, Dari data pada tahun 2016 di wilayah Kabupaten Tangerang terdapat Warga Negara Asing yang mempunyai ITK paling banyak dengan jumlah 98 orang (76 laki laki dan 22 perempuan), dan di wilayah Kota Tangerang yang paling sedikit adanya Warga Negara Asing yang memiliki ITK dengan jumlah 53 orang (36 laki laki dan 17 perempuan). Pada Tahun 2017 di wilayah Kabupaten Tangerang yang paling banyak adanya Warga Negara Asing memiliki ITK dengan jumlah 142 (105 laki-laki dan 37 perempuan), dan yang paling sedikit adanya Warga Negara Asing yang memiliki ITK ada di wilayah Kota Tangerang, dengan jumlah 22 orang (14 laki-laki dan 8 perempuan). Pada tahun 2018 yang terdapat banyak Warga Negara Asing yang memiliki ITK di wilayah Kabupaten Tangerang dengan jumlah 298 orang (245 laki-laki dan 53 Perempuan) dan yang paling sedikit di wilayah Kota Tangerang dengan jumlah Warga Negara Asing memiliki ITK 41 orang (27 laki-laki dan 14 perempuan). Pada Tahun 2019 di wilayah Kota Tangerang Selatan terdapat yang paling banyak Warga Negara Asing yang memiliki ITK yaitu sejumlah 33 orang (16 laki-laki dan 17 
perempuan) dan yang paling sedikit di wilayah Kota Tangerang yaitu 17 orang (10 laki-laki dan 7 perempuan).

\section{Data Warga Negara Asing yang Menyalahgunakan Izin Tinggal Kunjungan}

Warga Negara Asing yang dimaksud melakukan pelanggaran adalah apabila sengaja menyalahgunakan atau melakukan kegiatan yang tidak sesuai dengan maksud dan tujuan pemberian izin tinggal yang diberikan kepadanya. Pada tulisan kali ini penulis akan membahas mengenai Warga Negara Asing yang bekerja menggunakan ITK (Izin Tinggal Kunjungan) yang seharusnya menggunakan ITAS (Izin TInggal Terbatas). Di bawah ini merupakan data Warga Negara Asing dari 14 Negara yang melakukan pelanggaran ITK yang terdapat di Kantor Imigrasi Kelas I Tangerang Periode 2016 hingga Juni 2019 yang terdiri dari 3 wilayah yaitu Kota Tangerang, Kabupaten Tangerang, Kota Tangerang Selatan, Dari data pada tahun 2016 Warga Negara Asing yang banyak melakukan pelanggaran berasal dari negara China yaitu sebanyak 32 WNA dan tersebar paling banyak di wilayah Kabupaten Tangerang sebanyak 19 WNA dan yang paling sedikit tersebar di wilayah kota Tangerang yaitu sebanyak 3 WNA.

Warga Negara Asing yang paling sedikit melakukan pelanggaran adalah WNA berasal dari negara Italia, Jepang, Jerman, Nigeria sama sekali tidak ada WNA yang melakukan pelanggaran. Pada Tahun 2017 Warga Negara Asing yang banyak melakukan pelanggaran berasal dari negara China yaitu sebanyak 30 WNA dan tersebar paling banyak di wilayah Kabupaten Tangerang sebanyak 18 WNA dan yang paling sedikit tersebar di wilayah kota Tangerang yaitu sebanyak 3 WNA. Warga Negara Asing yang paling sedikit melakukan pelanggaran adalah WNA berasal dari negara Iran, Jepang, Nigeria sama sekali tidak ada WNA yang melakukan pelanggaran. Pada tahun 2018 Warga Negara Asing yang banyak melakukan pelanggaran berasal dari negara China yaitu sebanyak 37 WNA dan tersebar paling banyak di wilayah Kabupaten Tangerang sebanyak 22 WNA dan yang paling sedikit tersebar di wilayah kota Tangerang yaitu sebanyak 4 WNA. Warga Negara Asing yang paling sedikit melakukan pelanggaran adalah WNA berasal dari negara Italia, Jepang, Jerman dan Nigeria sama sekali tidak ada WNA yang melakukan pelanggaran.. Pada Tahun 2019 Warga Negara Asing yang banyak melakukan pelanggaran berasal dari negara China yaitu sebanyak 25 WNA dan tersebar paling banyak di wilayah Kabupaten Tangerang sebanyak 14 WNA dan yang paling sedikit tersebar di wilayah kota Tangerang yaitu sebanyak 3 WNA. Warga Negara Asing yang paling sedikit melakukan pelanggaran adalah WNA berasal dari negara Iran, Italia, Jerman, Jepang, Nigeria sama sekali tidak ada WNA yang melakukan pelanggaran. 
6. Efektifitas Pengawasan yang dilakukan oleh Kantor Imigrasi Kelas I Tangerang bagi Warga Negara Asing yang Menyalahi Izin Tinggal Kunjungan Menurut Undang-undang No 6 Tahun 2011 Tentang Keimigrasian

Warga Negara Asing merupakan seseorang yang tinggal dan menetap di sebuah negara tertentu namun bukan berasal dari negara tersebut juga tidak secara resmi terdaftar sebagai warga negara, yang memiliki tujuan yang beragam. Pada era globalisasi ini banyak sekali kita bisa lihat banyaknya Warga Negara Asing yang datang ke wilayah negara Indonesia. karena Indonesia memiliki banyak keunggulan yang dapat dimanfaatkan oleh pengusaha asing. Menurut peraturan di Indonesia setiap Warga Negara asing yang berkunjung ke Indonesia harus mendapatkan izin dari Pejabat Imigrasi sesuai dengan visa serta tujuan mereka datang ke Indonesia. ${ }^{10} \mathrm{Hal}$ itu sesuai dengan peraturan perundang-undangan yang berlaku di Indonesia, yang tercantum dalam Undang-Undang Nomor 6 Tahun 2011 Tentang Keimigrasian yang terdapat pada pasal 8 ayat (2) yang berbunyi" setiap orang asing yang masuk wilayah Indonesia wajib memiliki Visa yang sah dan masih berlaku, kecuali ditentukan lain berdasarkan Undang-undang ini dan perjanjian Internasional" dan pasal 9 ayat (1) yang berbunyi"Setiap orang yang masuk atau keluar wilayah Indonesia wajib melalui pemeriksaan yang dilakukan oleh pejabat Imigrasi di tempat pemeriksaan imigrasi".

Pengawasan Warga Negara Asing adalah seluruh rangkaian kegiatan yang ditujukan untuk mengontrol masuk dan keluarnya wilayah Indonesia melalui Tempat Pemeriksaan Imigrasi serta keberadaan Warga Negara Asing di Indonesia telah atau tidak sesuai maksud dan tujuan. Warga Negara Asing tersebut masuk ke Indonesia dengan visa yang diberikan sesuai dengan ketentuan Keimigrasian yang berlaku. Badan keimigrasian diberikan wewenang untuk mengamati dan memperlancar agar Warga Negara Asing yang berada di Indonesia terjaga keamananya dan haknya. Bukan hanya terjaga keamanan serta haknya, melainkan pula hal - hal lain yang bisa menjadi ancaman bagi warga pribumi atau warga negara Indonesia.

Berhubungan dengan perihal keimigrasian. Contohnya dalam hal permohonan izin tinggal Warga Negara Asing, Kantor Imigrasi melakukan pengawasan terhadap Warga Negara Asing, melakukan penyidikan kepada Warga Negara Asing yang mencurigakan, pengecekan dokumen perjalanan Warga Negara Asing, melaksanakan Tindakan Administratif Keimigrasian, melaksanakan putusan pengadilan negeri terhadap sanksi pidana kepada Warga Negara Asing yang melanggar peraturan undang undang. Warga Negara Asing yang datang ke Wilayah Indonesia wajib melaporkan kedatanganya ke kantor imigrasi untuk mendapatkan tanda masuk yang berupa cap dan membuat atau melakukan perpanjangan izin tinggal sesuai keperluanya dengan jujur.

${ }^{10}$ Ridwan Hr, Hukum Administrasi Negara, (Jakarta: Rajagrafindo), 2006, hlm 167-168 
Izin tinggal menurut pasal 48 ayat (3) Undang-Undang No.6 Tahun 2011 ada 5 (lima) jenis, antara lain Izin Tinggal Diplomatik, Izin Tinggal Dinas, Izin Tinggal Kunjungan, Izin Tinggal Terbatas, Izin Tinggal Tetap. ${ }^{11}$ Namun pada realita terdapat Warga Negara Asing yang menyalahgunakan izin yang telah diberikan dengan maksud dan tujuan yang berbeda, contoh kasus kecil, Warga Negara Asing menyalahgunakan izin tinggal kunjungan yang seharusnya hanya digunakan untuk berkunjung dan kunjungan kepada sanak familinya saja, namun Warga Negara Asing tersebut menggunakan izin kunjungan untuk bekerja secara diam-diam. Hal ini bertentangan dengan apa yang sudah dijelaskan dengan pasal 50 Undang-Undang No.6 Tahun 2011 tentang Keimigrasian mengenai diberikanya izin kunjungan. Jika Warga Negara Asing tersebut ingin bekerja, maka seharusnya ia membuat izin tinggal terbatas atau izin tinggal tetap sesuai dengan pasal 52 dan pasal 54. Berdasarkan situasi di atas telah terjadi penyalahgunaan izin tinggal, maka penyidik keimigrasian melakukan penyidikan kepada Warga Negara Asing yang menggunakan izin tinggal tersebut. Penyidik lalu membawa hal ini ke Kejaksaan dan membawanya ke Pengadilan Negeri untuk di proses dan dijatuhkanlah pidana atau akan dilakukan tindakan administratif berupa deportasi ke Negara asalnya sesuai dengan peraturan perundang-undangan.

Dalam penelitian ini didapatkan data Warga Negara Asing yang menyalahgunakan dokumen ITK untuk bekerja di Kantor Imigrasi Kelas 1 Tangerang pada tahun 2016 adalah 68 Warga Negara Asing dari 231 Warga Negara Asing yang memegang ITK, hal itu berarti 29,4 \% Warga Negara Asing melakukan pelanggaran pada tahun 2016. Warga Negara Asing tersebut tersebar dalam 3 wilayah yaitu Kabupaten Tangerang, Kota Tangerang dan Tangerang Selatan, dan yang paling banyak ada di Kabupaten Tangerang. Warga Negara Asing tersebut terdiri dari beberapa Negara. Bahwa ada 13 Negara yang warganya melakukan pelanggaran, dan yang paling banyak adalah Warga Negara Asing dari Negara China yang melakukan pelanggaran yaitu sebanyak 51 WNA.

Pada tahun 2017 ada 73 WNA yang melakukan pelanggaran dari 237 WNA yang memegang ITK atau sekitar 30,8\% . dan tersebar paling banyak di kabupaten Tangerang. Ini menunjukkan bahwa ada 11 Negara yang warganya melakukan pelanggaran, dan yang paling banyak adalah Warga Negara Asing dari Negara China yang melakukan pelanggaran yaitu sebanyak 30 WNA.

Pada tahun 2018 ada 91 WNA yang melakukan pelanggaran dari 420 WNA yang memegang ITK atau sekitar $31.6 \%$. dan tersebar paling banyak di kabupaten Tangerang. Ini menunjukkan bahwa ada 9 Negara yang warganya melakukan pelanggaran, dan yang paling banyak adalah Warga Negara Asing dari Negara China yang melakukan pelanggaran yaitu sebanyak 37 WNA.

Pada tahun 2019 periode Januari-Juni ada 38 WNA yang melakukan pelanggaran dari 81 WNA yang memegang ITK atau sekitar $46.9 \%$. dan

${ }^{11}$ Sudargo Gautama, Warganegara dan Orang Asing, ( Bandung: Cetakan 6), 1997, hlm 21 
tersebar paling banyak di kabupaten Tangerang. Ini menunjukkan bahwa ada 8 Negara yang warganya melakukan pelanggaran, dan yang paling banyak adalah Warga Negara Asing dari Negara China yang melakukan pelanggaran yaitu sebanyak 25 WNA.

Dilihat dari hasil penelitian penulis di Kantor Imigrasi Kelas 1 Tangerang Warga Negara Asing yang melakukan penyalahgunaan dokumen izin tinggal kunjungan periode 2016 sampai Juni 2019 setiap tahunnya mengalami peningkatan terutama pada tahun 2019. Penyalahgunaan izin sendiri semakin marak saat ini semenjak di berlakukannya bebas visa kunjungan pada 169 negara hal ini berdasarkan peraturan presiden Nomor 21 Tahun 2016. Bebas visa kunjungan yang dinilai terlalu luas dan pemberian tenggang waktu pada izin kunjungan yang terlalu lama membuat Warga Negara Asing memanfaatkan izin tinggal kunjungan untuk bekerja secara diam-diam. Penyalahgunaan visa kunjungan juga diakibatkan karena prosedur untuk mendapatkan visa terutama visa untuk bekerja yang memerlukan banyak waktu dan prosedur yang banyak. Sehingga Warga Negara Asing mengambil jalur alternatif dengan menggunakan Visa Kunjungan. Selain itu, penyalahgunaan penggunaan Visa terjadi karena adanya keengganan sebagian perusahaan atau Warga Negara Asing untuk mendaftarkan tujuan izin yang sebenarnya. Beberapa perusahaan enggan melakukukan izin karena membayar dana kompensasi sebesar USD 1.200/tahun sesuai permenaketrans no 16 tahun 2015 dan sulitnya mendapatkan izin untuk mempekerjakan atau mendirikan usaha.

Menurut Undang-undang no 6 tahun 2011 tentang keimigrasian visa kunjungan diberikan kepada Warga Negara Asing yang akan melakukan perjalanan ke Wilayah Indonesia dalam rangka kunjungan tugas pemerintahan, Pendidikan, sosial budaya, pariwisata, bisnis, keluarga, jurnalistik atau singgah untuk meneruskan perjalanan ke negara lain.

Berdasarkan pengamatan penulis pada Kantor Imigrasi Kelas 1 Tangerang terkait pelaksanaan fungsi keimigrasian, telah melakukan pengawasan terhadap Warga Negara Asing yang masuk ke wilayah Tangerang baik kota maupun kabupaten serta Tangerang Selatan. Pihak Imigrasi melakukan pengawasan dan penindakan sesuai dengan peraturan pemerintah No 31 Tahun 2013 pengawasan administratif pasal 180 dan pengawasan lapangan pasal 181 dan pihak Imigrasi telah membentuk Timpora dimaksudkan untuk mewujudkan pengawasan keimigrasian yang terkoordinasi dan menyeluruh terhadap keberadaan dan kegiatan Warga Negara Asing di Wilayah Indonesia. Jika Timpora menemukan Warga Negara Asing yang melanggar izin tinggal kunjungan kemudian dibawa ke Kantor Imigrasi kelas 1 Tangerang dan di tampung sementara di rumah detensi Imigrasi, berdasarkan peraturan pemerintah Nomor 31 Tahun 2013 tentang rumah detensi pasal 1 ayat (33) sebelum dideportasi ke negara masing-masing. Dalam rangka pematauan keberadaan Warga Negara Asing dan kegiatannya, pejabat imigrasi berwenang untuk: 
a. Menerima laporan dari masyarakat atau instansi pemerintah yang mengetahui pelanggaran keimigrasian. Laporan-laporan masyarakat terkait pelanggaran yang dilakukan oleh pekerja asing akan ditindaklanjuti dengan pengecekan, pemeriksaan dan penindakan hukum sesuai ketentuan yang ada.

b. Mendatangi tempat-tempat yang di duga dapat ditemukan bahan keterangan mengenai keberadaan Warga Negara Asing dan kegiatannya.

c. Memeriksa surat perjalanan atau dokumen keimigrasian Warga Negara Asing yang berada di Indonesia khususnya Tangerang.

Sementara itu, pelaksanaan pengawasan Warga Negara Asing di Kantor Imigrasi Tangerang terkendala oleh beberapa permasalahan. Beberapa kendala yang terjadi dikarenakan beban kerja di Kantor Imigrasi yang berat karena menangani cakupan wilayah tidak sedikit, jumlah pegawai yang bertugas dalam pengawasan tidak sebanding dengan jumlah Warga Negara Asing dan kurangnya partisipasi masyarakat dalam proses pengawasan Warga Negara Asing. yaitu $^{12}$ :

Hal ini sesuai dengan konsep penegakan hukum menurut Joseph Goldstein

1) Total Enforcement, yakni ruang lingkup penegakan hukum pidana seperti yang dirumuskan oleh hukum pidana substantif. Penegakan hukum pidana secara total ini tidak mungkin dilakukan, dikarenakan para penegak hukum dibatasi secara ketat oleh hukum acara pidana yang antara lain mencakup aturan-aturan penangkapan, penahanan, penggeledahan, penyitaan dan pemeriksaan pendahuluan. Hukum pidana substantif memberikan batasanbatasan tersendiri, misalnya dibutuhkan adanya aduan terlebih dahulu sebagai syarat penuntutan pada delik aduan.

Dalam Teori ini para penegak hukum seperti Imigrasi tidak dapat langsung melakukan pengawasan lapangan seperti penggeledahan, penangkapan, atau penahanan setiap saat, para pejabat imigrasi yang ditugaskan melakukan pengawasan dapat bertindak saat menerima laporan dan aduan dari masyarakat atau instansi pemerintah yang mengetahui pelanggaran keimigrasian Warga Negara Asing atau saat mendapat perintah tertulis yang ditandatangani oleh Pejabat Imigrasi yang berwenang, hal ini sesuai dengan peraturan pemerintah Nomor 31 Tahun 2013 pasal 182.

Kantor Imigrasi Kelas I Tangerang belum sepenuhnya melakukan koordinasi dengan masyarakat, pihak swasta dan juga LSM dalam pengawasan warga Negara asing di Daerah Tangerang, padahal dalam Undang- undang No 6 Tahun 2011 tentang Keimigrasian mulai pasal 66 sampai pasal 73 menghendaki adanya peranan secara aktif dari keimigrasian dan masyarakat dalam melakukan pengawasan keberadaan orang asing di Wilayah Indonesia.

${ }^{12}$ Dellyana Shant, Konsep Penegakan Hukum, (Yogyakarta: Liberty), 1988, hlm 32. 
Bahwa masyarakat merupakan salah satu faktor penting dalam pelaksanaan pengawasan Warga Negara Asing. Budaya Hukum masyarakat yang proaktif dapat mencapai keberhasilan suatu pengawasan keimigrasian tersebut seperti Rapat Koordinasi, Sosialisasi terhadap perusahaan dan masyarakat, dan perlibatan Instansi-instansi terkait dalam pelaksanaan pengawasan rutin dan pengawasan gabungan. ${ }^{13}$

2) Actual Enforcement, menurut Joseph Goldstein full enforcement ini dianggap sebagai harapan yang tidak realistis, dikarenakan adanya keterbatasan-keterbatasan dalam bentuk waktu, personil, alat-alat investigasi, dana dan sebagainya, yang semuanya mengakibatkan keharusan dilakukannya discretion (suatu kebijakan) dan sisanya inilah yang disebut actual enforcement.

Dalam teori ini Actual Enforcement menyebutkan bahwa pengawasan dan penindakan Kantor Imigrasi Kelas 1 Tangerang belumlah terlaksana dengan efektif, dikarenakan faktor-faktor penghambat antara lain jumlah personil bagian pengawasan dan penindakan yang tidak sebanding dengan Warga Negara Asing di Tangerang, dan kurangnya alat-alat dalam proses investigasi.

Untuk meminimalisir keterbatasan-keterbatasan tersebut seharusnya pihak Imigrasi dalam proses melakukan koordinasi pemantauan dan pengawasan warga Negara asing melibatkan berbagai instansi dari semua unsur tata pemerintahan seperti Polres, Dinas Tenaga Kerja dan Transmigrasi, dan juga instansi swasta seperti LSM, Hotel dan penyedia jasa pariwisata yang terdapat di Tangerang.

Selain itu, Direktorat Jendral Imigrasi membuat sebuah Aplikasi untuk mempermudah pengawasan Warga Negara Asing yaitu APOA (Aplikasi Pengawasan Orang Asing) yang diimplementasikan sejak tanggal 22 Mei 2015. Dengan adanya APOA ini pihak imigrasi tidak perlu melakukan sidak atau pengawasan lapangan secara berkala, karena APOA di bangun untuk memudahkan instansi eksternal seperti pemilik hotel, tempat penginapan atau perorangan yang memberikan tempat penginapan terhadap Warga Negara Asing untuk melakukan pelaporan. Dengan menggunakan APOA pemilik hotel, tempat penginapan tidak perlu datang ke imigrasi untuk melaporkan keberadaan Warga Negara Asing. Namun ternyata, hal ini masih kurang tepat untuk mengurangi ketidakefektifan pengawasan Warga Negara Asing karena pihak hotel, homestay, tempat penginapan dan masyarakat di Tangerang belum menjalankan aplikasi pelaporan orang asing (APOA) sebagai sarana pengawasan warga Negara asing. Hal tersebut dikarenakan koordinasi yang dilakukan dengan pihak eksternal seperti masyarakat masih belum berjalan dengan baik. Hal ini

${ }^{13}$ Saleh Wiramiharja, Langkah-langkah bar menunjang Peningkatan Profesionalisme Keimigrasian, (Jakarta: Pintu Gerbang No.45), 2002, hlm 21 
menunjukkan kurangnya sosialisasi yang dilakukan oleh Kantor Imigrasi Kelas I Tangerang tentang pengawasan Warga Negara asing

\section{Penyelesaian Hukum Bagi Warga Negara Asing yang Menyalahgunakan Izin Tinggal Kunjungan untuk Bekerja oleh Kantor Imigrasi Kelas 1 Tangerang}

Penyelesaian kasus Penyalahgunaan Izin menurut Undang - Undang Nomor 6 Tahun 2011 tentang Keimigrasian. Dalam kaitannya dengan penanggulangan terhadap warga negara asing yang menyalahgunakan Izin Keimigrasian dilakukan sesudah terjadinya atau terbukti adanya penyalahgunaan Izin Keimigrasian. Tindakan ini bersifat yuridis dan bisa juga bersifat adminitratif.:

\section{a. Tindakan Yuridis}

Dalam tindakan yuridis penyalahgunaan bisa mengikuti aturan Undang Undang Nomor 6 Tahun 2011 tentang Keimigrasian dalam Pasal 122 butir a : "setiap Orang Asing yang dengan sengaja menyalahgunakan atau melakukan kegiatan yang tidak sesuai dengan maksud dan tujuan pemberian Izin Tinggal yang diberikan kepadanya dipidana dengan pidana penjara paling lama 5 (lima) tahun dan pidana denda paling paling banyak Rp500.000.000,00 (lima ratus jutarupiah)" Jadi tindakan yuridis adalah orang asing yang dengan sengaja menyalahgunakan maksud pemberian izin keimigrasian dan harus dibuktikan di pengadilan oleh hakim dan kemudian dapat dikenakan sanksi pidana sesuai dengan ketentuan peraturan Perundang - undangan yang berlaku.

\section{b. Tindakan Administratif}

Menurut Pasal 75 Undang - Undang Nomor 06 Tahun 2011 yang mengatur mengenai tindakan keimigrasian terhadap orang asing diwilayah Indonesia, yaitu:

1) Pejabat Imigrasi berwenang melakukan Tindakan Administratif Keimigrasian terhadap Orang Asing yang berada di Wilayah Indonesia yang melakukan kegiatan berbahaya dan patut diduga membahayakan keamanan dan ketertiban umum atau tidak menghormati atau tidak menaati peraturan Perundang - undangan.

2) Tindakan Administratif Keimigrasian sebagaimana dimaksud pada ayat (1) dapat berupa:
a) Pencantuman dalam daftar Pencegahan atau Penangkalan;
b) pembatasan, perubahan, atau pembatalan Izin Tinggal;
c) larangan untuk berada di satu atau beberapa tempat tertentu di Wilayah Indonesia;
d) keharusan untuk bertempat tinggal di suatu tempat tertentu di Wilayah Indonesia;
e) pengenaan biaya beban; dan/atau
f) deportasi dari Wilayah Indonesia. 
c. Tindakan Administratif Keimigrasian berupa Deportasi dapat juga dilakukan terhadap Orang Asing yang berada di Wilayah Indonesia karena berusaha menghindarkan diri dari ancaman dan pelaksanaan hukuman di negara asalnya.

Menurut Joseph Goldstein dalam teori penegakan hukum, pada point kedua yaitu Full Enforcement yakni ruang lingkup penegakan hukum pidana yang bersifat Total Enforcement tersebut dikurangi oleh batasanbatasan. Dalam penegakan hukum ini para penegak hukum diharapkan dapat menegakan hukum secara maksimal ${ }^{14}$.

Penegakan Hukum adalah suatu proses yang mewujudkan keinginankeinginan hukum menjadi kenyataan, yang disebut keingian hukum disini adalah pikiran-pikiran badan pembuat Undang-undang yang dirumuskan dalam peraturan perundangan hukum ini. ${ }^{15}$ Peraturan-peraturan hukum Penegakan hukum pidana berkaitan erat dengan kemampuan aparatur negara dan kepatuhan masyarakat terhadap aturan yang berlaku. Penegakan hukum pidana tersebut merupakan bekerjanya proses peradilan pidana dengan sistem terpadu (Integrated Criminal Justice System) yang dilakukan oleh Polisi dan Penyidik Pegawai Negeri Sipil (PPNS), Jaksa, Hakim, Advokat dan Lembaga Pemasyarakatan atas dasar hukum yang berlaku. $^{16}$

Penegakan hukum yaitu Pihak Imigrasi bagian pengawasan dan penindakan haruslah berjalan agar tatanan fungsi keimigrasian berjalan sebagaimana mestinya, karena jika penegakan hukum tidak berjalan maka akan timbul pelanggaran maupun tindakan yang merugikan keamanan negara, sebagai salah satu contoh penyalahgunaan izin tinggal kunjungan yang digunakan untuk tujuan tertentu seperti yang telah diatur akan tetapi disalahgunakan untuk bekerja, hal ini menggambarkan tindak pidana dapat mempengaruhi warga negara asing untuk tidak menyalahgunakan izin yang telah diberikan pejabat Imigrasi.

Dari hasil penelitian yang sudah dilaksanakan oleh penulis, dimengerti bahwasannya dalam penyelesaian penegakan hukum Keimigrasian khususnya penindakan terhadap penyalahgunaan izin tinggal yang dilaksanakan pada Kantor Imigrasi Kelas 1 Tangerang dari tahun 2016 - Juni 2019, tindakan Projustisia relative jarang digunakan dalam penyelesaian perkara, hal tersebut bersumber dari ketidakefektifan dari berbagai point diantaranya memakan waktu yang relative cukup lama dalam prosesnya, pengalokasian anggaran yang jauh dari kata memadai,

\footnotetext{
${ }^{14}$ Dellyana Shant, Loc.Cit

${ }^{15}$ Satjipto Rahardjo, Masalah Penegakan Hukum Suatu Tinjauan Sosiologis, (Bandung: Cv Sinar Baru), 2009, hlm 24

${ }^{16}$ Barda Nawawi Arief, Masalah Penegakan Hukum dan Kebijakan Hukum Pidana Dalam Penanggulangan Kejahatan, (Jakarta: Kencana), 2010, hlm. 32
} 
serta sumber daya manusia dalam penindakan dan pengawasan Keimigrasian sangat terbatas. Sehingga Kantor Imigrasi Kelas 1 Tangerang lebih cenderung pada penyelesaian penyalahgunaan izin menggunakan upaya hukum Non Justisia yaitu Pendeportasian terhadap warga Negara asing untuk tidak masuk ke wilayah Indonesia dengan batas waktu yang ditentukan oleh Undang-undang.

Keputusan deportasi dikeluarkan oleh pejabat Imigrasi yang berwenang yaitu Kepala Kantor Imigrasi, dan keputusan tersebut harus disampaikan kepada warga negara asing yang dikenakan tindakan keimigrasian selambat-lambatnya 7 (tujuh) hari sejak tanggal penetapan. Selama warga negara asing yang dikenakan tindakan keimigrasian tersebut menunggu proses pendeportasian, warga negara asing tersebut ditempatkan di ruang detensi Imigrasi.

Undang-Undang Nomor 6 Tahun 2011 Tentang Keimigrasian Pasal 1 ayat (34) menentukan bahwa ruang detensi imigrasi merupakan tempat penampungan sementara bagi orang asing yang dikenai tindakan administratif Keimigrasian yang berada di Direktorat Jenderal Imigrasi dan Kantor Imigrasi dan pada Pasal 44 ayat (1) menentukan bahwa setiap orang asing yang berada di wilayah Indonesia dapat ditempatkan di ruang detensi Imigrasi apabila berada di wilayah Indonesia tanpa memiliki izin tinggal yang sah, atau dalam rangka menunggu proses pengusiran atau pendeportasian keluar wilayah Indonesia.

Penyelesaian penyalahgunaan izin terhadap warga Negara asing di Kantor Imigrasi Kelas 1 Tangerang dinilai kurang tegas dan dikarena upaya hukum yang dilakukan Non Justisia yaitu pendeportasian yang mengakibatkan warga Negara asing tidak jera dengan tindakan administarif keimigraisan tersebut, yang seharusnya pelanggaran izin tinggal penyelesaian menggunakan upaya hukum projustisia sesuai dengan peraturan perundang-undangan Nomor 6 Tahun 2011 tentang Keimigrasian dalam Pasal 122 butir a : "setiap Orang Asing yang dengan sengaja menyalahgunakan atau melakukan kegiatan yang tidak sesuai dengan maksud dan tujuan pemberian Izin Tinggal yang diberikan kepadanya dipidana dengan pidana penjara paling lama 5 (lima) tahun dan pidana denda paling paling banyak Rp500.000.000,00 (lima ratus jutarupiah)", penyelesaian yang kurang efektif ini justru dapat menambah angka pelanggaran izin tinggal yang masuk ke Indonesia karena tidak ada penerapan pidana lebih lanjut selain deportasi. Apabila penyelesaian masih tidak efektif maka akan berimbas negatif terhadap Negara seperti tingkatya pengangguran di Indonesia. 


\section{Penutup}

\section{Kesimpulan}

Berdasarkan hasil penelitian dan pembahasan maka dapat ditarik sebuah kesimpulan sebagai berikut:

a. Pengawasan Warga Negara Asing pada wilayah kerja Kantor Imigrasi Kelas I Tangerang sampai saat ini masih tidak efektif. Faktor penghambat ketidakefektifan itu yaitu Pemberlakuan kebijakan Bebas Visa Kunjungan yang diterapkan oleh pemerintah, berpengaruh terhadap jumlah dari target pengawasan Warga Negara Asing sehingga kurangnya jumlah pegawai pada bidang pengawasan dan penindakan yang memiliki tugas pokok sebagai pengawas Warga Negara asing di Lapangan. Kurangnya partisipasi masyarakat dalam pengawasan Warga Negara Asing, hal tersebut dipengaruhi oleh kurangnya sosialiasi mengenai pengawasan Warga Negara Asing Selain itu, kurangnya partisipasi masyarakat karena sebagian masyarakat masih bersifat apatis dan acuh tak acuh dengan keberadaan orang asing.

b. Penyelesaian Hukum bagi warga Negara asing yang menyalahgunakan izin tinggal di Kantor Imigrasi Kelas 1 Tangerang, melalu upaya hukum Tindakan Administratif Keimigrasian yaitu pendeportasian, tindakan projustisia relatif jarang digunakan dalam penyelesaian perkara penyalahgunaan izin, dikarena ada beberapa hambatan antara lain memakan waktu yang relatif cukup lama dalam prosesnya, sumber daya manusia dalam pengawasan dan penindakan yang sangat terbatas jika di bandingkan dengan warga Negara asing di Tangerang, kurang adanya kerjasama masyarakat dan penjamin ketika pemeriksaan warga Negara asing yang dijamin dilakukan

\section{Saran}

Berdasarkan kesimpulan di atas, maka penulis akan menyampaikan beberapa saran untuk dapat dijadikan masukan sebagai berikut:

1. Petugas Imigrasi hendaknya meningkatkan pengawasan terhadap keberadaan dan kegiatan warga Negara asing, meningkatkan koordinasi antar instansi terkait meningkatkan sarana penunjang operasional dengan adanya peningkatan tersebut diharapkan petugas Imigrasi dapat bekerja lebih maksimal, Penambahan jumlah personil di bidang pengawasan dan penindakan dalam mengawasi warga Negara asing sehingga menjangkau pengawasan di dalam kota maupun di kabupaten mengingat wilayah kerja yang luas, Peningkatan sosialisasi oleh Kantor Imigrasi Kelas 1 Tangerang tentang peraturan perundang-undangan sehingga memberikan informasi yang jelas kepada warga Negara asing, perusahaan-perusahaan yang mempekerjakan Tenaga kerja asing dan masyarakat dan Masyarakat Tangerang diharapkan mau bekerjasama dengan petugas Imigrasi Kantor Imigrasi Kelas I Tangerang dengan melakukan pengaduan mengenai keberadaan atau kegiatan orang asing yang ada disekitarnya.

2. Tindakan projustisia sebaiknya lebih diefektifkan dalam penegakan hukum terhadap tindak pidana penyalahgunaan Izin Tinggal Keimigrasian, karena dengan adanya sanksi pidana ini diharapkan dapat menimbulkan efek jera kepada pelaku dan warga 
Negara asing lainnya supaya tidak melakukan tindak pidana imigrasi serupa yaitu penyalahgunaan izin.

\section{Daftar Pustaka}

Agusmidah. Dilematika Hukum Ketenagakerjaan Tinjauan Politik Hukum. Medan: PT.Softmedia, 2011.

Ali, Mohammad. Pendidikan untuk Pembangunan Nasional. Jakarta: Grasindo, 2009.

Ashari, Khansa. Kamus Hubungan Internasional. Bandung: Nuansa Cendekia Indonesia. Jakarta: Sinar Grafika, 2015.

Arief, Barda, Nawawi. Masalah Penegakan Hukum dan Kebijakan Hukum Pidana Dalam Penanggulangan Kejahatan. Jakarta: Kencana, 2010.

Arikunto, Suharsimi, Prosedur Penelitian Suatu Pendekatan Praktek, Jakarta: PT.Rineka ,2006.

Ashofa, Burhan. Metode Penelitian Hukum. Jakarta: PT.Rineka Cipta, 2004.

Budiono, Abdul Rachmat Hukum Perburuhan di Indonesia. Jakarta: PT.Rajagrafindo, 1995.

Chazawi, Adami. Pelajaran Hukum Pidana Bagian 2. Jakarta: Raja Grafindo, 2002.

Gunadi, Ismu dan Jonaedi Efendi. Cepat dan Mudah Memahami Hukum Pidana. Jakarta: Kencana Prenamedia Group, 2014.

Gautama Sudargo, Warga Negara Asing dan Orang Asing, Bandung: Cetakan 6, 1997

Hamidi, Jazim dan Charles Christian. Hukum Keimigrasian Bagi Orang Asing di Indonesia. Jakarta: Sinar Grafika, 2015.

H.R.Ridwan, Hukum Administrasi Negara, Jakarta: Rajagrafindo, 2006

Marpaung, Leden. Asas Teori Praktik Hukum Pidana. Jakarta: Sinar Grafika, 2012.

Muladi dan Barda Nawawi Arief. Teori-teori dan Kebijakan Pidana. Bandung: Raja Grafindo, 1998. 
Rahardjo, Satjipto. Masalah Penegakan Hukum Suatu Tinjauan Sosiologis, Bandung, Cv Sinar Baru, 2009.

Roeslan. Stelsel Pidana Indonesia. Jakarta: Bina Asara, 2004

Sapoetra, Karta G. Hukum,Perburuhan di Indonesia. Jakarta: Bina Aksara, 2004.

Shant, Dellyana. Konsep Penegakan Hukum. Yogyakarta: Liberty, 1998.

Soekanto, Soerjono. Pengantar Penelitian Hukum. Jakarta: UI Press, 2015.

Wiramiharja, Saleh. Langkah-langkah Baru Menunjang Peningkatan Profesionalisme Keimigrasian: Jakarta: Pintu Gerbang No 45, 2002

Wijayanti, Herlin. Hukum Kewarganegaraan dan Keimigrasian. Malang: Bayumedia Publishing, 2011.

Indonesia. Peraturan Menteri Nomor M.HH.OT.01.01 Tahun 2010 Tentang Organisasi dan Tata Kerja Kementerian Hukum dan HAM RI.

Indonesia. Peraturan Pemerintah No 31 Tahun 2013 tentang Peraturan Pelaksanaan Undang-undang Keimigrasian

Indonesia. Undang-undang No 6 Tahun 2011 tentang Keimigrasian

Kurniawan, Bugie. 2008. Analisis Terhadap Pelaksanaan Manajemen Pemberian VOA yang dilaksanakan oleh Direktorat Jenderal Imigrasi dan Tempat Pemeriksaan Imigrasi.http://lib.ui.ac.id.

Lazuardi, RF. 2018. Tinjauan Pustaka Tentang Warga Negara Asing Visa Kunjungan Tindak Pidana Penyalahgunaan Visa Kunjungan dan Deportasi. http://repository.unpas.ac.id.

Santoso, Imam. 2004. Peran Keimigrasian dalam Rangka Peningkatan Ekonomi dan Pemeliharaan Ketahanan Nasional secara Seimbang. Tesis Hukum. Jakarta: Universitas Krisnadwipayana.

Sinta. 2016. Pelaksanaan Pengenaan Restribusi IMTA oleh Dinas Sosial dan Tenaga Kerja Kabupaten Badung pada PT.SPA Sukses Pratama Kuta. Skripsi. Denpasar: Universitas Udayana.

Ahmad jazuli. 2018. Eksitensi Tenaga Kerja Asing di Indonesia dalam Perspektif Hukum Keimigrasian. Jurnal Media Hukum. 12(1):6. 
JURNAL HUKUM REPLIK

Vol 7 No 2, September 2019

P-ISSN: 2337-9251, E-ISSN: 2597-9094

Anonim. 2018. Tenaga Kerja Asing di Indonesia Meningkat 11\% pada 2018. https://databooks.katadata.co.id.

Ayu, H. Penegakan Hukum Keimigrasian Terhadap Penyalahgunaan Visa http://eprints.ums.ac.id.

Fatwa, Desy. 2018. 8 Dampak Tenaga Kerja Asing di Indonesia. https://ilmugeografi.com.

Kantor Imigrasi Kelas 1 Non Tpi Tangerang. https://tangerang-imigrasi.go.id. 